\title{
FAKTOR-FAKTOR YANG MEMPENGARUHI KETERLAKSANAAN EVALUASI PROGRAM BIMBINGAN DAN KONSELING
}

\author{
Aip Badrujaman \\ e-mail: aip_bj@yahoo.com \\ Bimbingan dan Konseling FIP Universitas Negeri Jakarta
}

\begin{abstract}
Abstrak: ini bertujuan untuk mengetahui faktor-faktor yang mempengaruhi keterlaksanaan evaluasi Program Bimbingan dan Konseling SMP Negeri di Jakarta Timur. Menggunakan metode studi deskriptif, penelitian ini dilakukan di Sekolah Menengah Pertama (SMP) di Wilayah kota Jakarta Timur dalam bulan Maret sampai dengan September 2012. Dengan menggunakan teknik sampling yang convenience sampling, diperoleh 18 Sekolah yang dipilih adalah sebagai sampel penelitian. Hasil penelitian menunjukkan bahwa terdapat dua faktor utama yang menyebabkan guru BK di SMPN Jakarta Timur tidak melakukan evaluasi program bimbingan dan konseling, yaitu: (a) kurangnya keterampilan melakukan evaluasi dan (b) beban kerja yang tinggi. Faktor-faktor yang mempengaruhi keterlaksanaan secara rendah adalah (a) hasil program BK sulit diukur, (b) kurang lengkapnya data BK, (c) kurangnya anggaran dana/keuangan BK, (d) kurang mampu menetapkan kriteria evaluasi BK yang relevan, (e) takut kelemahannya diketahui adanya tenaga yang merangkap (teacher-counselior), (f) ketersediaan rasio guru BK masih kurang, dan (g) kurang dukungan kepala sekolah. Peneliti menyarankan (a) perlu mengkaji beban kerja guru BK, (b) perlu kerjasama berbagai pihak (dinas pendidikan, perguruan tinggi LPTK) untuk meningkatkan keterampilan guru BK dalam melakukan evaluasi program bimbingan dan konseling.
\end{abstract}

Kata kunci: faktor-faktor, evaluasi, program, bimbingan, konseling

\section{FACTORS AFFECTING THE EVALUATION OF GUIDANCE AND COUNCELING PROGRAM}

\begin{abstract}
The study aimed at revealing the factors affecting the implementation of the evaluation of guidance and counselling program in Junior Secondary Schools in East Jakarta. Employing descriptive method, the study was performed in March through September 2012. Using convenience sampling, the study identified 18 schools as samples. The study discovered two main factors causing guidance and counselling teachers not performing the guidance and counselling program: (a) inability to perform the evaluation and (b) the high load of the teachers' tasks. The low factors include the result of guidance and counselling is difficult to measure, (b) incomplete data of guidance and counselling, (c) insufficient budget, (d) inability to set up relevant evaluation criteria, (e) unwillingness to reveal the existence of teacher-counsello, (f) the lack of gudance and counselling teachers, and (g) insufficient support from the svhool principa. The study suggests (a) to review the work load of the guidance and councelling teachers, (b) to develop the cooperation among related intitutions to imptove the competence of gudance and councelling teachers in the evaluation of guidance and counselling program.
\end{abstract}

Keywords: factors, evaluation, program, guidance, counselling

\section{PENDAHULUAN}

\section{Latar Belakang Masalah}

Evaluasi merupakan hal yang penting, bukan hanya fungsinya sebagai alat untuk membuat perbaikan, akan tetapi karena evaluasi juga merupakan akuntabilitas terhadap program, atau layanan pendidikan yang diberikan kepada siswa. Melalui evaluasi, pendidik akan mempu melihat berbagai kelemahan yang ada dalam program yang diselenggarakan. Purwanto dalam Lubis (2002) mengungkapkan bahwa dengan evaluasi diperoleh informasi tentang (1) kemajuan dan perkembangan siswa setelah mengikuti kegiatan belajar mengajar selama jangka waktu tertentu,

(2) keberhasilan suatu metode pengajaran oleh guru,

(3) kekurangan/keburukan dari hasil evaluasi yang selanjutnya dapat dijadikan pedoman/bahan informasi yang akurat untuk mengambil keputusan, baik oleh guru, kepala sekolah, maupun pihak yang terkait.

Layanan bimbingan konseling sebagai bagian yang tidak terpisahkan dari program pendidikan dituntut untuk dapat melakukan evaluasi terhadap 
berbagai layanan yang diselenggarakan. Tuntutan terhadap hal ini dapat dilihat dalam tugas pokok guru pembimbing, berdasarkan Keputusan MENPAN No. 84 Tahun 1993 Bab II pasal 3 mengenai tugas pokok guru pembimbing ialah menyusun program bimbingan, melaksanakan program bimbingan, evaluasi pelaksanaan bimbingan, analisa hasil pelaksanaan bimbingan, dan tindak lanjut dalam program bimbingan terhadap peserta didik yang menjadi tanggung jawabnya.

Tantawy (1995) menjelaskan lebih lanjut yang dimaksud evaluasi pelaksanaan bimbingan merupakan kegiatan menilai keberhasilan layanan dalam bidang bimbingan pribadi, sosial, karier, dan belajar. Kegiatan mengevaluasi itu juga meliputi juga kegiatan menilai keberhasilan jenis-jenis layanan yang dilaksanakan, yakni layanan orientasi, informasi, penempatan/penyaluran, bimbingan kelompok, serta konseling kelompok.

Evaluasi terhadap layanan bimbingan konseling pada era sekarang ini memiliki peran yang sangat penting dan menentukan dalam kerangka pendidikan nasional. Hal ini dapat terlihat pada aspek budi pekerti yang menjadi salah satu indikator syarat kelulusan. Banyak kalangan, termasuk kepala sekolah berpendapat bahwa guru bimbingan konseling merupakan orang yang paling mengetahui dan paling tepat untuk memberikan penilaian terhadap aspek budi pekerti tersebut (Suara Merdeka, 2004). Hal ini tentunya menjadi sebuah peluang sekaligus tantangan guru bimbingan konseling untuk melakukan evaluasi yang mangkus.

Meskipun evaluasi penting, akan tetapi pada kenyataannya guru pembimbing masih mengalami kesulitan dalam melakukannya. Penelitian yang dilakukan Rachmalia (2006) mengenai pelaksanaan tugas pokok guru pembimbing di Kecamatan Cempaka Putih menunjukkan bahwa untuk aspek evaluasi bimbingan konseling masih belum banyak dilakukan. Hal ini dapat dilihat bahwa guru pembimbing yang melakukan evaluasi layanan untuk mengetahui seberapa sukses layanan yang diberikan yang menjawab "selalu" sebanyak 18.75\%, "sering" sebanyak $25 \%$, "kadang-kadang" sebanyak $50 \%$, "pernah" sebanyak $6.25 \%$, dan "tidak pernah" sebanyak $0 \%$.

Hasil penelitian Rachmalia (2006) mengenai kinerja evaluasi tersebut sejalan dengan temuan Muryani (2008) yang menunjukkan bahwa kinerja evaluasi guru BK SMA di Kecamatan Kembangan Jakarta Barat masih rendah, yaitu sebesar 21.01\%. Kinerja evaluasi yang buruk juga ditemukan pada penelitian yang dilakukan Yusuh (2011) yang mengungkapkan bahwa banyak guru tidak melakukan evaluasi program BK di sekolah.

\section{Rumusan Masalah}

Berdasarkan identifikasi masalah di atas, maka peneliti berpikir bahwa masalah seputar evaluasi program bimbingan dan konseling terlalu luas. Untuk itu, maka peneliti bermaksud membatasi masalah penelitian sebagai berikut: (1) penelitian dilakukan di SMP Negeri Wilayah Jakarta Timur, (2) masalah yang diteliti adalah faktor-faktor yang mempengaruhi guru bimbingan dan konseling melakukan evaluasi program.

Berdasarkan pembatasan masalah, maka masalah dalam penelitian ini dirumuskan sebagai berikut: "Faktor-faktor apa sajakah yang mempengaruhi guru BK SMP Negeri di Wilayah Kota Jakarta Timur melakukan evaluasi program bimbingan dan konseling?"

\section{Kajian Teori}

\section{Evaluasi Perencanaan Program Bimbingan}

Evaluasi perencanaan program bimbingan merupakan evaluasi yang dilakukan untuk mengetahui apakah perencanaan yang dibuat sudah baik atau belum. Perencanaan program bimbingan dan konseling terdapat dalam kurikulum bimbingan (guru BK sering menyebutnya silabus BK).

Sebagaimana kita ketahui bahwa kurikulum bimbingan pada dasarnya terdiri atas dua komponen besar, meliputi (1) peta kompetensi, di mana bagian terkecilnya adalah tujuan layanan; dan (2) strategi mencapai tujuan layanan (program). Dua komponen kurikulum bimbingan ini merupakan suatu yang khas, sehingga memerlukan cara/teknik tersendiri dalam melakukan evaluasi. Berdasarkan pemahaman itu, maka evaluasi perencanaan program bimbingan dapat kita bagi lagi menjadi evaluasi tujuan program bimbingan, dan evaluasi input program bimbingan.

\section{Evaluasi Proses Program Bimbingan}

Banyak ahli yang berpendapat bahwa evaluasi proses penting dilakukan. Stufflebeam dalam model evaluasi CIPP yang dikembangkannya menyebutnya sebagai komponen proses (process) (Stufflebeam $\mathcal{E}$ Shinhfield, 1985). Istilah lain untuk evaluasi proses disampaikan oleh Scriven yang menyebutnya sebagai evaluasi formatif. Gysbers (2006) menggunakan istilah program evaluation untuk evaluasi terhadap aspek proses dalam program. Ahli evaluasi yang juga dan bahkan sangat menekankan evaluasi proses adalah Stake yang mengemukakan evaluasi responsif. Meskipun istilah evaluasi proses yang digunakan para ahli evaluasi berbeda, akan tetapi sesungguhnya para ahli evaluasi tersebut sependapat bahwa aspek proses 
merupakan bagian penting dalam pelaksanaan evaluasi terhadap suatu program.

Stufflebeam mengatakan bahwa evaluasi proses merupakan pengecekan yang berkelanjutan atas implementasi perencanaan (Stufflebeam \& Shinkfield, 1985: 175). Pendapat tersebut menegaskan, bahwa evaluasi proses merupakan evaluasi yang dilakukan untuk melihat apakah pelaksanaan program sesuai dengan strategi yang telah direncanakan. Dalam ungkapan yang lain, evaluasi proses bertujuan untuk mengidentifikasikan atau memprediksi dalam proses pelaksanaan, seperti cacat dalam desain prosedur atau implementasinya. Scriven berpendapat bahwa evaluasi proses adalah bagian integral dari proses perkembangan (pengembangan). Evaluasi ini menyediakan feedback bagi perencanaan dan juga membangun suatu perbaikan pelaksanaan. Secara umum Scriven mengatakan bahwa evaluasi proses (formative) dilakukan untuk membantu staf memperbaiki apapun yang mereka laksanakan atau bangun/kembangkan. Dengan demikian, dapat diambil kesimpulan bahwa evaluasi proses bertujuan untuk menyediakan informasi sebagai dasar memperbaiki program, serta untuk mencatat, dan menilai prosedur kegiatan dan peristiwa.

Bagian terpenting yang harus dipahami dalam evaluasi proses dalam program bimbingan adalah penekanannya pada usaha perbaikan yang dapat dilakukan berkenaan dengan aspek proses program bimbingan. Dalam melaksanakan program bimbingan, guru bimbingan dan konseling memiliki perencanaan bimbingan yang disebut satuan layanan (satlan). Meskipun guru bimbingan dan konseling telah membuat satuan layanan dengan baik, akan tetapi sangat mungkin ketika dilaksanakan, perencanaan tersebut tidak sesuai dengan harapan guru bimbingan dan konseling. Pada konteks tersebut, maka guru bimbingan dan konseling perlu untuk menelaah berbagai kelemahan yang terdapat dalam program tersebut, dan akhirnya dapat menyusun rencana dan melaksanakan program yang lebih baik.

Keberadaan evaluasi proses yang dilakukan oleh guru bimbingan dan konseling sesungguhnya memberikan jaminan bahwa pelaksanaan progam bimbingan secara berkelanjutan mengalami perbaikan terus menerus. Selain itu, dengan adanya evaluasi proses ini perbaikan terhadap pelaksanaan program bimbingan dapat dilakukan segera, tidak perlu menunggu satu semester atau satu tahun baru melakukan perbaikan. Misalnya saja, guru bimbingan dan konseling melakukan evaluasi proses pada kegiatan program bimbingan yang dilakukan, di satu kelas. Berdasarkan evaluasi proses yang dilakukan, maka metode yang digunakan guru bimbingan dan konseling dalam program bimbingan tidak efektif. Hal ini terlihat dari siswa yang pasif, serta minat yang kurang mengikuti kegiatan bimbingan. Berdasarkan hasil evaluasi proses tersebut, ketika guru bimbingan dan konseling melaksanakan kegiatan program bimbingan di kelas yang berbeda, metode yang digunakan sudah mengalami perbaikan.

Usaha perbaikan (di dalamnya terdapat identifikasi kelebihan, kelemahan, hambatan) tersebut tentunya dapat dilakukan apabila guru bimbingan dan konseling memiliki cukup informasi/data berkenaan dengan kelebihan dan kelemahan program yang dilakukan. Dalam evaluasi proses ini, guru bimbingan dan konseling perlu memonitor kegiatan, berinteraksi terus menerus, serta dengan mengobservasi kegiatan. Kegiatan monitoring tentunya memerlukan berbagai macam instrumen. Pada evaluasi proses, instrumen yang dapat digunakan banyak sekali, seperti angket, pedoman observasi, tes, dan lain sebagainya.

3. Evaluasi Hasil Program Bimbingan

Evaluasi hasil adalah evaluasi yang bertujuan untuk mengukur, menginterpretasikan, dan menilai pencapaian program (Hadi \& Mutrofin, 2006: 176). Feedback atas pencapaian/prestasi ini penting selama pelaksanaan program dan sebagai sebuah kesimpulan. Evaluasi hasil juga bertujuan mengumpulkan deskripsi dan penilaian terhadap luaran (outcome) dan menghubungkan itu semua dengan objektif, tujuan, input, dan informasi proses, serta untuk menginterpretasikan kelayakan dan keberhargaan program. Evaluasi hasil dapat dilakukan dengan membuat definisi operasional dan mengukur kriteria objektif, melalui mengumpulkan data dari siswa.

Evaluasi hasil dalam program bimbingan dan konseling, khususnya pada progam bimbingan, tentunya berbeda dengan evaluasi hasil dalam pembelajaran bidang studi. Hasil yang hendak dicapai melalui pembelajaran bidang studi umumnya bersifat jangka pendek, artinya dalam jangka waktu 6 bulan atau satu semester perubahan kompetensi dapat terlihat. Kondisi ini berbeda dengan hasil yang diharapkan dalam program bimbingan dan konseling, khususnya program bimbingan. Pada program bimbingan dan konseling khususnya program bimbingan pembentukan kompetensi yang dikehendaki melalui program bimbingan dicapai melalui sebuah proses. Gysbers (2006) menyatakan bahwa pada program bimbingan (guidance curriculum) kompetensi yang akan dibentuk melalui tiga tahapan, yaitu (1) perceptualization, (2) conseptualization, dan (3) generalization. Berdasarkan 
pemahaman, bahwa pembentukan kompetensi tersebut melalui sebuah proses, maka aspek hasil bukanlah merupakan aspek tunggal. Artinya, kita masih dapat membagi lagi aspek hasil pada program bimbingan menjadi beberapa bagian berdasarkan jangka waktunya.

Beberapa ahli mengajukan berbagai konsep mengenai hal ini. Pusat Kurikulum (2004) mengajukan adanya penilaian segera (laiseg), penilaian jangka pendek (laijapen), dan penilaian jangka panjang (laijapan). Menurut pandangan penulis, melakukan evaluasi terhadap hasil segera setelah program bimbingan dilakukan, sulit untuk diterapkan. Hal ini dikarenakan kompetensi belum nampak secara jelas. Penulis berpendapat bahwa evaluasi pada aspek segera lebih cocok ditujukan untuk melihat sejauh mana tanggapan siswa terhadap kegiatan program bimbingan yang dilaksanakan, bukan untuk melihat capaian hasilnya. Sehingga untuk evaluasi segera penulis lebih melihatnya sebagai evaluasi proses.

4. Evaluasi Program Konseling

Evaluasi program konseling merupakan kegiatan yang dilakukan untuk mengetahui efektifitas program konseling yang diselenggarakan di sekolah. Evaluasi program konseling dapat dilakukan dengan beberapa metode. Pertama, evaluasi program konseling dapat dilakukan dengan menggunakan metode survey. Pada desain survei, konselor mengembangkan angket yang berisi tanggapan siswa (tentunya yang mendapatkan program konseling) terhadap proses konseling yang dilakukan. Metode survei ini lebih cocok apabila konselor hanya ingin mengetahui secara keseluruhan keberhasilan program konseling yang diselenggarakan. Metode survei ini memberikan informasi yang minim mengenai perubahan yang diakibatkan oleh intervensi. Kondisi ini akan membuat guru $\mathrm{BK} /$ konselor sulit untuk melaporkan perkembangan siswa pada program konseling.

Metode lain yang juga dapat digunakan untuk mengevaluasi program konseling adalah metode studi kasus. Pada metode studi kasus, guru BK/Konselor melakukan evaluasi pada siswa (yang mengikuti program konseling) selama kegiatan konseling dilakukan. Dalam istilah yang berbeda Borders \& Drury (h.20) menyatakan bahwa evaluasi yang tepat untuk program konseling adalah evaluasi formatif. Evaluasi formatif yang dimaksud adalah evaluasi yang dilakukan secara terus menerus sepanjang konseling diselenggarakan. Hal utama dalam evaluasi ini adalah pengumpulan data yang dilakukan sepanjang tahun.

Pada evaluasi, termasuk juga evaluasi program konseling, data merupakan bagian yang sangat penting dalam rangka pengambilan kesimpulan/ keputusan yang tepat. Keberadaan data siswa ini tentunya memungkinkan guru BK/konselor melakukan dua kegiatan. Pertama, melalui data yang dimiliki, guru BK/konselor dapat mengetahui sejauh mana efektivitas program konseling yang dilakukannya. Efektivitas program konselor tersebut dapat dilihat berdasarkan pencapaian siswa terhadap tujuan-tujuan yang ditetapkan (goals) dalam konseling. Selain itu, keberadaan data juga dapat digunakan konselor untuk memberikan laporan perkembangan siswa yang menjadi kliennya. Laporan sebagai bentuk tanggung jawab konselor pada apa yang dilakukannya.

E. Faktor Yang Mempengaruhi Pelaksanaan Evaluasi Program BK

Evaluasi dalam program bimbingan dan konseling didasarkan pada dua program besar dalam layanan yang diselenggarakan, yaitu (1) bimbingan dan (2) konseling. Kedua program ini, meskipun berkaitan akan tetapi memiliki karakteristik yang khas. Suparto (1986) menjelaskan faktor yang mempengaruhi hasil guna bimbingan adalah kedudukan layanan bimbingan dan fasilitas yang ada, serta sikap anggota staf sekolah terhadap layanan bimbingan. Faktor-faktor yang mempengaruhi hasil guna konseling adalah tafsiran tentang konseling sebagai kegiatan profesional, keadaan para konselor yang ditugaskan di sekolah dalam hal orientasi profesional pengalaman, dan mutu kerjanya, serta bantuan dan kerjasama diantara semua anggota staf sekolah, terutama guru.

Gysbers (2006) mengemukakan bahwa dalam membantu pendekatan yang berorientasi pada perbaikan dalam evaluasi program, premis dasar dibawah ini penting untuk dipahami, yaitu: (1) konselor sekolah harus terlibat secara personel dalam mengevaluasi program mereka; (2) evaluasi program yang diadakan pada front end of implementation adalah penting untuk menentukan goal yang sesuai dan kompetensi siswa yang dilayani dalam program; (3) evaluasi pada banyak segi dalam prosesnya akan melibatkan observasi terhadap perilaku, wawancara, menelaah produksi media, rekaman lain, focus group discussion (FGD), forum terbuka, survei, pengukuran yang terstandar, penilaian ahli, serta telaah teman (peer review); (4) evaluasi program akan sukses apabila didukung oleh administrator, diadakan oleh konselor sekolah dengann berkolaborasi dengan yang lain, yang menjadi customers.

Selain pemahaman akan premis dasar tersebut, Winkel \& Hastuti (2006:580) mengemukakan faktor yang mempengaruhi hasil guna bimbingan adalah kedudukan layanan bimbingan dan fasilitas yang 
ada, serta sikap anggota staf sekolah terhadap layanan bimbingan.

Myrick (2003) mengemukakan bahwa terdapat lima alasan mengapa guru pembimbing tidak melakukan evaluasi program bimbingan dan konseling. Kelima alasan tersebut saling berkaitan satu dengan lainnya. Kelima alasan guru pembimbing tidak melakukan evaluasi, meliputi: (1) guru pembimbing tidak memiliki waktu, (2) guru pembimbing tidak memiliki pengetahuan dan keterampilan, (3) adanya ketakutan guru pembimbing terhadap akuntabilitas, (4) perasan nyaman guru pembimbing dengan apa yang ada, serta (5) persepsi guru pembimbing bahwa hasil sulit untuk diukur.

\section{METODE PENELITIAN}

\section{Jenis Penelitian}

Penelitian ini termasuk dalam penelitian deskriptif dengan menggunakan metode survei.

\section{Waktu dan Tempat Penelitian}

Penelitian ini dilakukan di sekolah menengah pertama (SMP) di Wilayah kota Jakarta Timur. Waktu yang dipilih untuk pelaksanaan penelitian ini adalah bulan Maret sampai dengan bulan September 2012.

\section{Prosedur Penelitian}

\section{a. Sumber Data}

Populasi dalam penelitian ini adalah guru bimbingan dan konseling SMP di wilayah kota Jakarta Timur. Guru tersebut merupakan pegawai negeri sipil. Adapun teknik sampling yang digunakan adalah convinience sampling. Teknik sampling ini dipilih karena kesulitan dalam meminta waktu guru BK untuk memberikan informasi mengenai pelaksanaan evaluasi program BK dan faktor yang mempengaruhinya. b. Teknik Pengumpulan Data

Teknik pengumpulan data pada penelitian ini adalah penyebaran instrumen penelitian. Untuk mendapatkan data yang sesuai dengan tujuan penelitian, maka peneliti membuat instrumen penelitian yang dapat mengungkapkan faktor-faktor yang mempengaruhi guru bimbingan dan konseling dalam melakukan evaluasi program bimbingan dan konseling. Instrumen yang digunakan dalam penelitian ini adalah berbentuk wawancara dengan dua pilihan jawaban, yaitu "ya" dan "tidak".

c. Teknik Analisis Data

Pada penelitian ini, data-data yang diperoleh akan dihitung dengan menggunakan rumus persentase. Hal ini guna mendapatkan data mengenai gambaran faktor-faktor yang mempengaruhi pelaksanaan evaluasi program BK.

\section{HASIL DAN PEMBAHASAN}

\section{Hasil Penelitian}

Berdasarkan data hasil penelitian, diketahui terdapat tujuh penyebab yang memiliki persentase di atas $50 \%$, meliputi: kurangnya anggaran, kurang mampu menetapkan criteria, serta ketersediaan rasio guru BK dan siswa masing-masing sebesar $60 \%$. Penyebab ketidakterlaksanaan yang memberikan kontribusi sebesar 70\% didapat dari beban kerja terlalu banyak, kurang lengkapnya data BK, dan adanya tenaga yang merangkap. Sedangkan, penyebab yang memiliki persentase paling tinggi adalah kurangya keterampilan melakukan evaluasi program BK, yaitu sebesar $80 \%$. Untuk lebih jelasnya dapat dilihat pada tabel 1.

Tabel 1. Faktor yang Mempengaruhi Keterlaksanaan Evaluasi Program BK

\begin{tabular}{|l|c|}
\hline \multicolumn{1}{|c|}{ Penyebab Ketidakterlaksanaan } & $\begin{array}{c}\text { Persentase } \\
(\%)\end{array}$ \\
\hline Beban kerja terlalu banyak & 70 \\
\hline $\begin{array}{l}\text { Tidak/kurang memiliki keterampilan dalam } \\
\text { evaluasi program BK }\end{array}$ & 80 \\
\hline Hasil dari program BK sulit diukur & 40 \\
\hline Kurang lengkapnya data BK & 70 \\
\hline Kurangnya anggaran dana/keuangan BK & 60 \\
\hline $\begin{array}{l}\text { Kurang mampu menetapkan kriteria evaluasi } \\
\text { BK yang relevan }\end{array}$ & 60 \\
\hline Takut kelemahannya diketahui & 20 \\
\hline $\begin{array}{l}\text { Adanya tenaga yang merangkap (teacher- } \\
\text { counselor) }\end{array}$ & 70 \\
\hline Ketersediaan rasio guru BK masih kurang, & 60 \\
\hline Kurang dukungan dari kepala sekolah & 10 \\
\hline
\end{tabular}

Berdasarkan ungkapan responden, diketahui bahwa penyebab utama tidak dilaksanakannya evaluasi program BK secara prioritas adalah karena beban yang terlalu berat, kurang memiliki keterampilan, tidak bisa menentukan kriteria evaluasi, rendahnya dukungan kepala sekolah, serta rangkap jabatan.

Tabel 2. Penyebab Utama Tidak Dilaksanakan Evaluasi Program B

\begin{tabular}{|l|c|c|c|c|}
\hline & Frequency & Percent & $\begin{array}{c}\text { Valid } \\
\text { Percent }\end{array}$ & $\begin{array}{c}\text { Cumulative } \\
\text { Percent }\end{array}$ \\
\hline Beban & 1 & 6,7 & 6,7 & 6,7 \\
40,0 & 40,0 & 46,7 \\
\hline Dukungan & 1 & 6,7 & 6,7 & 53,3 \\
\hline Keterampilan & 4 & 26,7 & 26,7 & 80,0 \\
\hline Kriteria & 2 & 13,3 & 13,3 & 93,3 \\
\hline Rangkap & 1 & 6,7 & 6,7 & 100,0 \\
\hline \multicolumn{1}{|c|}{ Total } & 15 & 100,0 & 100,0 & \\
\hline
\end{tabular}




\section{Pembahasan}

Berdasarkan deskripsi data yang telah dipaparkan, maka terdapat beberapa temuan penelitian yang menarik. Pertama, diketahui bahwa terdapat dua faktor yang dominan (didukung oleh data secara kuantitatif, dan kualitatif), yaitu: (1) keterampilan melakukan evaluasi program bimbingan dan konseling, serta (2) beban kerja yang tinggi pada guru BK di sekolah. Temuan kedua adalah faktor yang mempengaruhi keterlaksanaan evaluasi program BK lebih ditentukan oleh faktor yang bersifat internal dibandingkan eksternal.

Berdasarkan data yang diperoleh, diketahui bahwa terdapat dua faktor utama yang mempengaruhi keterlaksanaan evaluasi program BK di SMPN Jakarta Timur. Faktor pertama adalah keterampilan melakukan evaluasi program BK. Keterampilan merupakan faktor yang sangat penting. Keterampilan membuat seorang profesional dapat melakukan evaluasi. Tanpa keterampilan dapat dipahami bahwa guru BK mengalami kesulitan untuk melaksanakan program BK dan bahkan tidak melakukannya. Kurangnya keterampilan guru BK dalam melakukan evaluasi program disebabkan banyak faktor. Salah satunya adalah kajian mengenai evaluasi program BK relatif baru berkembang pesat setelah adanya tuntutan mengenai akuntabilitas. Di Amerika, metode dan teknik evaluasi program BK berkembang pesat mulai tahun 2000-an. Diltz dan Mason (2010) sependapat dengan para ahli seperti Housley, Mc Daniel, Nims, James, Hughey yang menyatakan bahwa konselor diminta untuk terlibat dalam praktik akuntabilitas yang memberikan dukungan efektifitas program BK di sekolah. Memperkuat pendapat Diltz dan Mason, Stanbergeer \& Smith (1996) mencatat adanya peningkatan tuntutan akuntabilitas terhadap program konseling. Hal senada juga diungkapkan oleh White (2007) mengutip pendapat Studer yang menyatakan bahwa akuntabilitas merupakan tuntutan bagi pendidik termasuk juga konselor untuk efektifitas dari program yang diselenggarakannya. Bahkan Gysbers (2003) menyebutkan bahwa akuntabilitas bukan hanya sebuah tuntutan akan tetapi menjadi sebuah kebutuhan bagi konselor.

Faktor kedua yang menjadi penyebab guru BK tidak melaksanakan evaluasi program BK adalah beban kerja. Berdasarkan SK MENPAN no 84 tahun 1993, rasio guru pembimbing dengan siswa adalah 1 berbanding 150. Sampai dengan sekarang, masih didapati guru pembimbing yang membimbing lebih dari 150 siswa. Kondisi ini tentunya memberikan beban tersendiri bagi guru pembimbing yang pada akhirnya tidak mampu melayani seluruh siswa yang seharus- nya mendapatkan layanan. Dengan beban kerja dan waktu kerja yang tidak seimbang, guru pembimbing hanya mampu melakukan konseling pada beberapa orang siswa saja. Pada kenyataannya, di sekolah, guru pembimbing tidak hanya menyelenggarakan layanan BK, akan tetapi seringkali guru pembimbing ditugaskan pada kegiatan di luar wilayah kerjanya, seperti guru piket, wali kelas, dan lain sebagainya. Kondisi ini semakin membuat waktu yang dapat digunakan menjadi terbatas. Apalagi, jika terdapat aturan sekolah dimana konseling tidak boleh dilakukan pada jam pelajaran. Sejatinya guru pembimbing dapat memberikan layanan konseling bagi siswa yang bermasalah, akan tetapi karena adanya keterbatasan tenaga dan waktu, maka siswa tidak mendapatkan layanan yang seharusnya.

\section{Implikasi}

Berdasarkan hasil dan pembahasan penelitian di atas, maka terdapat beberapa implikasi penelitian, antara lain: (1) beban kerja yang tinggi dapat membuat guru BK tidak optimal dalam menyelenggarakan layanan BK termasuk juga dalam melakukan evaluasi program BK, serta (2) ketidakmampuan guru BK dalam melakukan evaluasi dapat berdampak buruk pada penyelenggaraan program BK.

\section{PENUTUP}

\section{Kesimpulan}

Berdasarkan pembahasan hasil penelitian yang telah dipaparkan, maka dapat diambil beberapa kesimpulan penelitian sebagai berikut.

Pertama, terdapat dua faktor utama yang menyebabkan guru BK di SMPN Jakarta Timur tidak melakukan evaluasi program bimbingan dan konseling, yaitu: (1) kurangnya keterampilan melakukan evaluasi program BK, dan (2) beban kerja yang tinggi

Kedua, faktor-faktor yang mempengaruhi keterlaksanaan secara rendah, yaitu (1) hasil dari program BK sulit diukur, (2) kurang lengkapnya data BK, (3) kurangnya anggaran dana/keuangan BK, (4) kurang mampu menetapkan kriteria evaluasi BK yang relevan, (5) takut kelemahannya diketahui adanya tenaga yang merangkap (teacher-counselor), (6) ketersediaan rasio guru BK masih kurang, serta (7) kurang dukungan dari kepala sekolah.

\section{Saran}

Berdasarkan kesimpulan di atas, maka peneliti mengajukan beberapa saran terkait dengan evaluasi program BK sebagai berikut.

Pertama, perlu adanya upaya untuk mengkaji beban kerja guru BK agar dapat menyelengarakan tugas pokok secara efektif. Kedua, perlu kerja sama 
berbagai pihak (dinas pendidikan, perguruan tinggi LPTK) untuk mengembangkan program yang dapat meningkatkan keterampilan guru BK dalam melakukan evaluasi program bimbingan dan konseling.

\section{DAFTAR PUSTAKA}

Gysbers, N C \& Henderson, P. (2006). Developing \& managing your school guidance and counseling program. Alexandria: American Counseling Asociation.

Rachmalia, N. (2006). Faktor-faktor penghambat pelaksanaan tugas pokok guru pembimbing. Skripsi :
Universitas Negeri Jakarta.

Suparto, H. (1990). Diktat kuliah penilaian program bimbingan dan konseling. Universitas Negeri Jakarta.

Kartadinata, S., dkk. (2003). Panduan tekniks analisis tugas perkembangan dan instrumen tugas perkembangan. Universitas Negeri Bandung.

Stufflebeam, D \& Shienfield, A. (1985). Systematic evaluation. Boston: Kluwer-Nijhoff Publihing.

Tantawy R. (1995). Manajemen BK. Jakarta : Press.

Winkel, W S \& Hastuti, S. (2006). Bimbingan dan Konseling di Institusi Pendidikan. Yogyakarta: Media Abadi. 